\title{
Marteiliosis in American oysters Crassostrea virginica reared in France
}

\author{
Tristan Renault*, Nathalie Cochennec, Bruno Chollet
}

IFREMER, Laboratoire de Biologie et d'Ecologie des Invertébrés Marins, Unité de Recherche en Pathologie et Immunologie Générales, BP 133, F-17390 La Tremblade, France

\begin{abstract}
Progeny of Crassostrea virginica oysters, introduced into France in 1992, were reared at 3 different locations. A survey was taken of these young $C$. virginica oysters during 1993. Histological and electron microscopical examination revealed a parasite interpreted as a Marteilia-like protozoan in 1 oyster. The structure and the initial stages of the developmental cycle of this parasite are described for the first time in American oysters. However, no mature spores were detected. Thus, exact identification of the protozoan is difficult. This study indicates that American oysters could be infected with Marteilia spp. during cohabitation with Marteilia-infected native bivalves in France.
\end{abstract}

KEY WORDS: American oyster - Crassostrea virginica $\cdot$ Marteiliosis - Marteilia-like parasite

\section{INTRODUCTION}

The Pacific oyster Crassostrea gigas was introduced into France in the late 1960s at the same time as the disappearance of the Portuguese oyster $C$ angulata, which was destroyed by iridoviral infections (Comps \& Duthoit 1976, Comps et al. 1976). Considering the economic importance of the Pacific oyster to the French shellfish industry, the possible appearance of major diseases among this species could be catastrophic. This led to investigations into the replacement of $C$. gigas with another non-indigenous species, $C$. virginica.

After a histological examination of 80 specimens to confirm the absence of recognized pathogens, Crassostrea virginica adult oysters were imported from England to the IFREMER Laboratory in La Tremblade (Charente-Maritime, France) in 1992. Progeny of these oysters were deployed in the wild in April 1993 to test their growth performance. In July 1993, a histological survey was performed among these 1 yr old oysters. Histological examination revealed a protozoan parasite in the epithelia of the digestive gland in 1 oyster. Ultrastructural analysis and observation of the first steps of the developmental cycle suggest that the protozoan

\footnotetext{
•E-mail: trenault@ifremer.fr
}

might belong to the genus Marteilia. We report herein, for the first time, the presence of a Marteilia-like parasite in the American oyster $C$. virginica, in France.

\section{MATERIALS AND METHODS}

Specimens and sampling procedures. After histological examination of 80 fixed Crassostrea virginica adult oysters to confirm the absence of lesions and recognized pathogens, 50 live oysters with the same origin were brought from England (Dr S. Utting, Fisheries Laboratory Conway) to the IFREMER laboratory in La Tremblade (Charente Maritime, France) in 1992. Animals were maintained under quarantine and, $6 \mathrm{wk}$ after their importation, spawning was induced. Larvae were reared at IFREMER's hatchery and then, after histological examination, young spat were transferred to the Bouin nursery (Vendée, France) for growth until April 1993. The parents were destroyed after spawning.

In March 1993, 30 juveniles from the Bouin nursery were examined by light and electron microscopy. After this control, spat were placed in the wild in April 1993, in 2 different locations, Bourcefranc and Arvert (Charente Maritime, France) (Fig. 1), to test their growth performances or were held in the IFREMER laboratory 


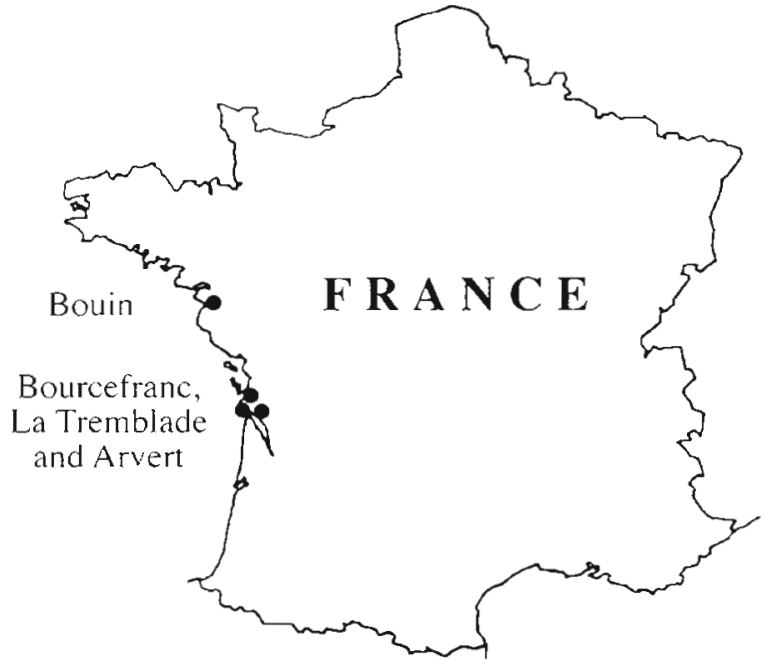

Fig. 1 Locations of Crassostrea virginica samples collected for light and electron microscopical analysis

in La Tremblade. In July 1993, 30 oysters from each site (Bourcefranc, Arvert and La Tremblade) were examined by light and electron microscopy.

Light microscopical examination. After oysters were removed from the shell, they were sagittaly sectioned, then one half was placed in Davidson's fluid, the other half in Carson's fixative. Samples fixed in Davidson's fluid were dehydrated through an ascending ethanol series, cleared in xylene and embedded in wax, sectioned at 3 to $4 \mu \mathrm{m}$ thickness, stained with Hemotoxylin and Eosin, and carefully checked for lesions and pathogens.

Electron microscopical examination. Pieces of gill and digestive gland were taken from tissues stored in Carson's fixative, rinsed for $48 \mathrm{~h}$ in $0.2 \mathrm{M}$ cacodylate buffer, fixed in $2.5 \%$ glutaraldehyde in $0.2 \mathrm{M}$ cacodylate buffer at a pH of 7.2 , and post-fixed in $1 \%$ osmium tetroxide in the same buffer. Specimens were cleared in propylene oxide and embedded in Epon resin. Sections for light microscopy of $1 \mu \mathrm{m}$ were stained in $2.5 \%$ toluidine blue in $1 \%$ aqueous sodium borate solution. Ultrathin sections were collected on copper grids and double stained with uranyl acetate and lead citrate and observed in a JEOL JEM 1200 EX transmission electron microscope at $60 \mathrm{kV}$

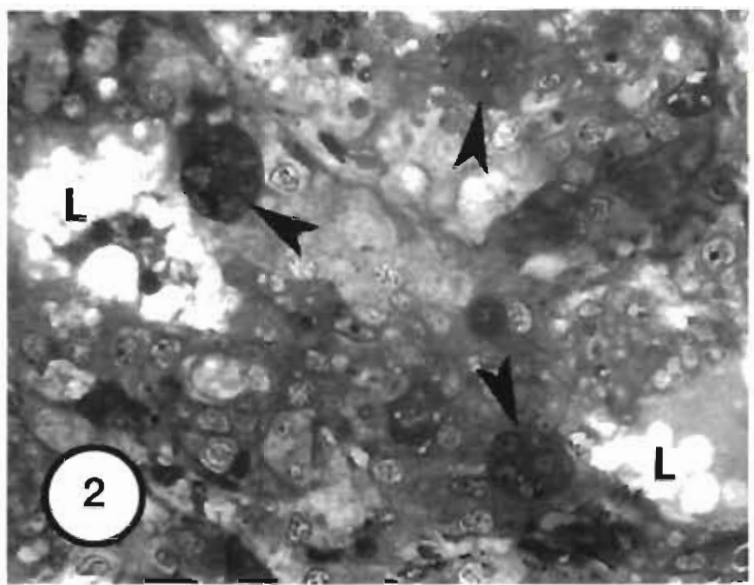

Fig. 2. Marteilia-like parasite infecting Crassostrea virginica oyster. Light microscopy. Toluidine blue stain. Multinucleate stages of the parasite (arrowheads) in the epithelium of digestive tubules of the host. L: lumen of digestive tubule. $\times 800$

\section{RESULTS}

A parasite infection was found in the epithelia of the digestive gland of 1 American oyster from Avert (Fig. 2). The parasite consisted of uninucleate or multinucleate, spherical to elongated cells, and had a maximum dimension of up to $12 \mu \mathrm{m}$ (Figs. $3 \& 4$ ).

Ultrastructurally, the primary cells were delimited by a plasmalemma without a cell wall or fibrillar layer. The cytoplasm contained large multivesicular bodies and ribosomes. Free vermiform or oblate haplosporosomes up to $50 \mathrm{~nm}$ in diameter and up to $265 \mathrm{~nm}$ long were also found in the cytoplasm (Fig. 5). Fusiform striated inclusions were observed in the same cell compartment (Fig. 6). These structures consisted of membranes of endoplasmic reticulum cisternae alternating with electron-dense zones in periodic arrays (30.6 nm periodicity). A small number of vesicular mitochondria containing a few cristae were also seen (Figs. 3 \& 4). Some primary cells contained 1 or 2 small spherical cells (secondary cells), 2.8 to $4.7 \mu \mathrm{m}$ in diameter (Fig. 7). Initially, the secondary cells (presporangia or sporangial primordia at that moment) were delimited by 2 parallel membranes. The cytoplasm lacked multivesicular bodies, haplosporosomes and

Figs. 3 to 8. Marteilia-like parasite infecting Crassostrea virginica. Electron microscopy. Fig. 3. Early stage of Marteilia-like parasite $\mathrm{C}_{1}$ : primary cell; $\mathrm{N}$ : nucleus of the primary cell; $\mathrm{H}$ : haplosporosomes; $\mathrm{S}$ : striated bodies; HC: host cell. Scale bar $=1 \mu \mathrm{m}$. Fig. 4. Early stage of Marteilia-like parasite. $C_{1}$ : primary cell; $N_{1}$ : nucleus of the primary cell $C_{2}$ : secondary cell; $N_{2}$ : nucleus of the secondary cell; HC: host cell. Scale bar $=1 \mu \mathrm{m}$. Fig. 5. Vermiform to oblate haplosporosomes (arrowheads) of a primary cell. Scale bar $=200 \mathrm{~nm}$. Fig. 6. Fusiform striated bodies (arrowheads) in the cytoplasm of a primary cell. Scale bar $=500 \mathrm{~nm}$. Fig. 7 . A presporangium or sporangial primordia $\left(C_{2}\right)$ observed inside a primary cell $\left(C_{1}\right)$. Scale bar $=1 \mu$ m. Fig. 8 . A spore pnmordium $(S)$ within a sporont $\left(\mathrm{C}_{2}\right)$. Polymorphic inclusion bodies (arrowheads) can be detected in the cytoplasm of the sporont and the spore primordium. $C_{1}$ : primary cell; H.C: host cell. Scale bar $=500 \mathrm{~nm}$ 

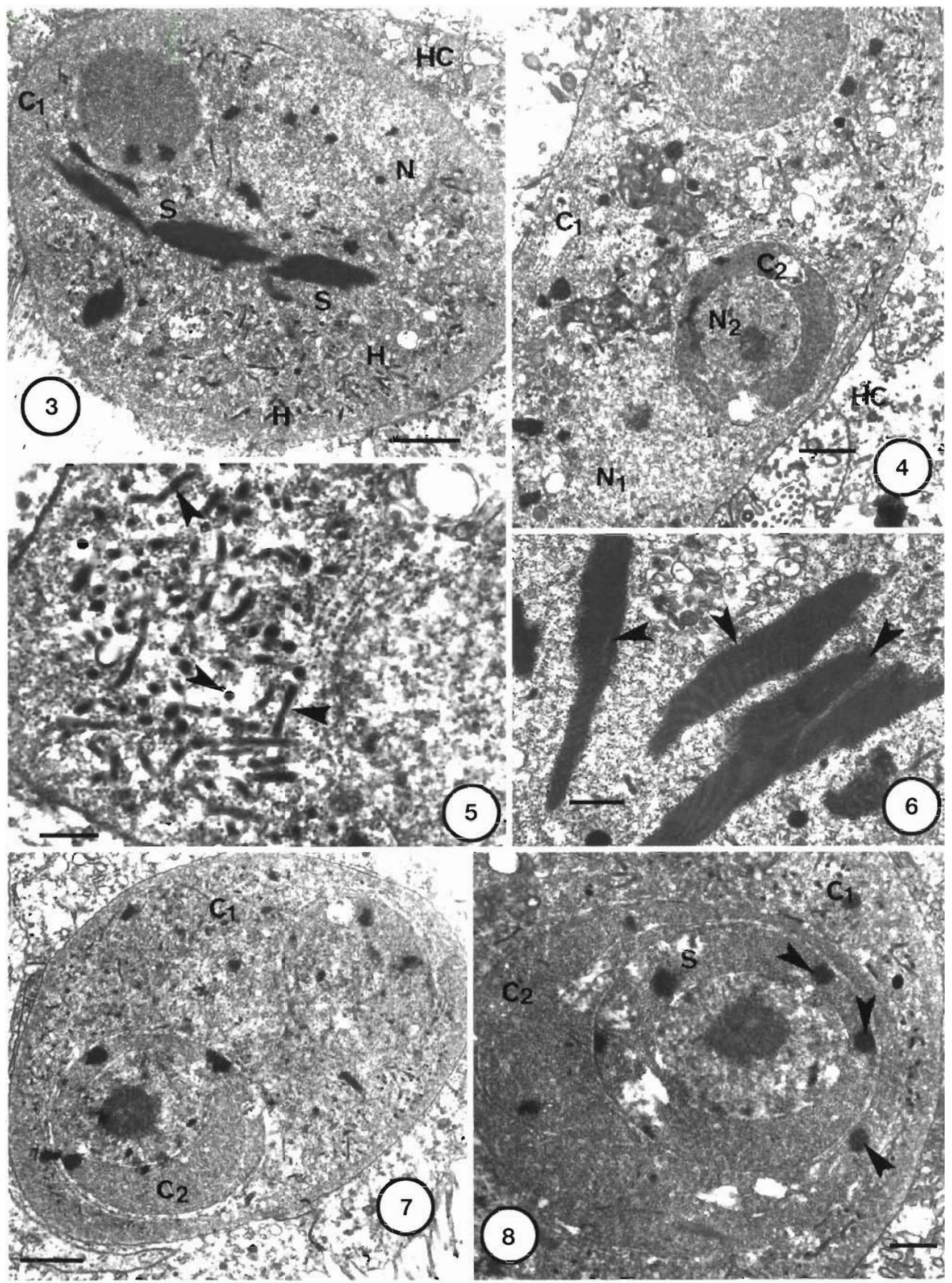
striated inclusions. Only mitochondria, numerous ribosomes and endoplasmic cisternae were observed. The cytoplasm became progressively vacuolated and contained electron-dense inclusion bodies, $250 \mathrm{~nm}$ in diameter. No mature spores were detected in the affected oyster, although formation of tertiary cells (spore primordia) was sometimes observed (Fig. 8).

The host reaction consisted of hemocytic infiltration of connective tissue in the digestive gland and epithelia of digestive diverticula where parasites were located. This reaction at some places in the oyster resulted in focal, massive concentrations of hemocytes.

\section{DISCUSSION}

Our study reports the presence of a protozoan infection in epithelia of the digestive gland of 1 American oyster reared in Arvert (Charente Maritime, France). The structure and the initial stages of the detected parasite were characteristic of the early stages observed in the developmental cycle of parasites belonging to the genus Marteilia (Grizel et al. 1974).

The morphological features of the observed parasite and the histological location of the presporulation stages are in agreement with those described by Perkins (1976) for the species Marteilia refringens, but they also agree with those of $M$. maurini (Comps et al. 1982, Auffret $\&$ Poder 1985). The only differences found by Comps et al. (1982) between these 2 species of Marteilia were their respective hosts and some structures of the spores: the shape of the haplosporosomes of the outer sporoplasm and the structure of the spore envelope. Without mature spores from infected oysters, we could not determine the species of Marteilia present.

Parasites of the genus Marteilia have now been reported in several species of marine molluscs in different parts of the world (Grizel et al. 1974, Comps et al. 1975, Perkins \& Wolf 1976, Comps 1977, Cahour 1979, Comps 1983, Auffret \& Poder 1985). The present study reports for the first time the detection of a Marteilia-like protozoan in the American oyster Crassostrea viriginica held in French waters.

Moreover, the presence of a Marteilia-like parasite in American oysters reared for 3 mo at a French location (Arvert, Charente Maritime) where native bivalve molluscs are infected with Marteilia spp. and the absence of parasites among oysters reared in the IFREMER hatchery and nursery suggest that the American oyster infection had accurred after contact with infected bivalves present in the wild. Similarly, controlled introductions of healthy oysters, Ostrea chilensis from Chile and $O$. angasi from Australia, into locations along the French coasts where $O$. edulis was naturally infected by $M$. refringens led to the trans- mission of the infection to these newly introduced species (Grizel et al. 1983, Bougrier et al. 1986). No parasite was observed in the oysters cultivated in Bourcefranc (Charente Maritime) or in those reared at the IFREMER hatchery (La Tremblade, Charente Maritime) or at the IFREMER nursery (Bouin, Vendée). For oysters held at the IFREMER center, this result was expected because the laboratory is free of Marteilia spp.; for those reared in Bourcefranc, the site is in the open sea where Marteilia spp. infections are more rarely observed among native bivalves.

Our report demonstrates the possible susceptibility of the American oyster Crassostrea virginica to a Marteilia-like parasite in France. Thus, the American oyster is not considered to be a possible substitute for $C$. gigas in France. Moreover, this study underlines the potential danger of introducing non-indigenous species of bivalves for rearing without sufficient control protocols.

\section{LITERATURE CITED}

Auffret M, Poder M (1985) Recherches sur Marteilia maurini, parasite de Mytilus edulis sur les côtes de Bretagne-Nord. Revue Trav Inst Pêch marit 47(1-2):105-109

Bougrier S, Tigé G, Bachère E, Grizel H (1986) Ostrea angasi. An acclimatization to French Coasts. Aquaculture 58 : $151-154$

Cahour A (1979) Marteilia refringens and Crassostrea gigas. Mar Fish Rev 41:19-20

Comps M (1977) Marteilia lengehi n. sp. parasite de l'huitre Crassostrea cucullata Born. Revue Trav Inst Pèch marit 40\{2):347-349

Comps M (1983) Marteilia christenseni n. sp. parasite du lavignon Scrobicularia piperata P. (Mollusque Pélécypode). Revue Trav Inst Pêch marit 47(1-2):99-104

Comps M, Bonami JR, Vago C, Campillo A (1976) Une virose de l'huître portugaise (Crassostrea angulata LMK). C r Acad Sci, Paris (Sér D) 282:1991-1993

Comps M, Duthoit JL (1976) Infection virale associée à la 'maladie des branchies' de l'huître portugais Crassostrea angulata LMK. Cr Acad Sci, Paris (Sér D) 283:1595-1596

Comps M, Grizel H, Tige G, Duthoit JL (1975) Parasites nouveaux de la glande digestive des mollusques marins Mytilus edulis L. et Cardium edule L. C r Acad Sci, Paris (Sér D) 281:179-181

Comps M, Pichot Y, Papagianni P (1982) Recherche sur Martilia maurini n. sp. parasite de la moule Mytilus galloprovincialis Lmk. Revue Trav Inst Pêch marit 45:211-214

Grizel H, Comps M, Bonami JR, Cousserans F, Duthoit JL, Le Pennec MA (1974) Recherches sur l'agent de la maladie de la glande digestive d'Ostrea edulis Linné. Sci Pèche 40: $7-30$

Grizel $H$, Comps $M$, Raguennes D, Le Borgne $Y$, Tigé $G$, Martin AG (1983) Bilan des essais d'acclimatation d'Ostrea chilensis sur les côtes de Bretagne. Revue Trav Inst Pêches marit 46:209-225

Perkins FO (1976) Ultrastructure of sporulation in the European flat oyster pathogen Marteilia refringens. Taxonomic implications. J Protozool 23(1):64-74

Perkins FO, Wolf PH (1976) Fine structure of Martellia sydneyi sp. n., Haplosporidian pathogen of Australian oysters J Parasitol 62:528-538 